\title{
Duties of Care Under the Revised Uniform Partnership Act
}

\author{
Gerard C. Martin†
}

Since 1914, the Uniform Partnership Act ("UPA") has provided background principles to resolve disputes between partners who lack an explicit partnership agreement. ${ }^{2}$ However this Act was revised in $1994,{ }^{3}$ resulting in several fundamental alterations. Among other changes, this Revised Uniform Partnership Act ("RUPA") added an explicit duty of care of partners to each other and the partnership. ${ }^{4}$ Whereas the UPA was silent on such a duty, implicitly deferring both to the common law of agency and to a specialized partnership case law derived therefrom, ${ }^{5}$ the RUPA seeks explicitly to provide an exclusive delineation of partners' fiduciary duties to the partnership and to each other. ${ }^{6}$

This Comment discusses the RUPA's duty of care provision and seeks to determine when and how the Acts "gross negligence" duty of care standard ${ }^{7}$ should be applied. Specifically, the Comment focuses on three questions: (1) Does the RUPA's "gross negligence" standard replace the common law's agency-based

† B.A. 1993, Yale University; J.D. 1998, The University of Chicago.

1 Uniform Partnership Act (1914), 6 Uniform Laws Annotated ("ULA") 125 (West 1995).

2 Until recently, the UPA was law in every state except Louisiana. Allan W. Vestal, Choice of Law and the Fiduciary Duties of Partners Under the Revised Uniform Partnership Act, 79 lowa L Rev 219, 221 n 12 (1994). As enacted, the UPA varied little between states, and remained unchanged in its original form for over seventy-five years. Id.

3 Uniform Partnership Act (1994), 6 ULA 1 (West 1995). This Act was adopted by the National Conference of Commissioners on Uniform State Laws. It is commonly known as the Revised Uniform Partnership Act ("RUPA"), and that is how it will be referred to for the rest of the Comment.

4 The revision to the original UPA began in the fall of 1987, upon recommendation by an American Bar Association ("ABA") subcommittee. See UPA Revision Subcommittee of the Committee on Partnerships and Unincorporated Business Organizations, Should the Uniform Partnership Act Be Revised?, 43 Bus Law 121, 123 (1987) ("ABA Report"). In August 1994, the National Conference of Commissioners on Uniform State Laws completed its work on the final version of the RUPA, which subsequently has become effective in four states, and has been enacted by eight others with effective dates ranging from January 1, 1999 to January 1, 2001. ULA 1997 Master Edition Pamphlet 9-79.

- UPA § 21, 6 ULA 608; ABA Report, 43 Bus Law at 151 (cited in note 4); Restatement (Second) of Agency \& 14A (ALI 1958); RUPA § 404 Comment 1, 6 ULA 59.

- RUPA \& 404(a) \& Comment 1, 6 ULA 58-59.

7 RUPA \$ 404(c), 6 ULA 58. 
standard of liability for partner actions?; (2) Does the RUPA's "gross negligence" standard replace the business judgment rule when a partner makes managerial decisions regarding the partnership business; and (3) If so, is it subject to the procedural and substantive limitations of the rule, such as requiring the partner to be reasonably informed and to use a reasonable decisionmaking process? In addressing these issues, this Comment explores both the inner and outer boundaries of the RUPA's duty of care provision.

These issues are important to the law of partnership for several reasons. Most notably, because the formation of partnerships is often informal, or even inadvertent, the default rules embodied in partnership legislation frequently fill the void left where there is no, or only an incomplete, partnership agreement. Also, because the duty of care default rule is unwaivable except in limited circumstances under the RUPA, ${ }^{9}$ would-be partners need to be aware of how courts will apply it. Otherwise, partners are left with a mandatory, yet undefined, legal obligation, a situation that one observer has characterized as "most problematic."

There is virtually no case law interpreting the RUPA duty of care standard. ${ }^{11}$ Further, scholars disagree vehemently regarding both what the duty of care standard is under the UPA case law and the common law of agency, and what that standard should be. Part I of this Comment briefly examines this debate and surveys the duty of care among partners under the UPA and the common law. It concludes that judges, when interpreting the duty of care among partners under the UPA and the underlying common law, have employed a bifurcated standard-implicitly distinguishing between the common law standard of care and skill for agents, and the deferential standard for managerial decisions embodied in the business judgment rule. Part II begins by examining the policy motivations and intentions of the drafters of the RUPA. Applying these observations to the RUPA § 404(c), it

${ }^{8}$ See Restatement (Second) of Agency § 14A (distinguishing agents and partners); id $\S 379$ (agent's duty to principal of care and skill).

- Section 103(b)(4) of the RUPA states that the partnership agreement may not "unreasonably reduce the duty of care under Section 404(c) ..." 6 ULA 17. Official Comment 6 to $\S 103$ states that "determining the outer limit in reducing the standard of care is left to the courts." Id at 18.

${ }^{10}$ Robert M. Phillips, Comment, Good Faith and Fair Dealing Under the Revised Uniform Partnership Act, 64 U Colo L Rev 1179, 1183 (1993) (discussing implications for partnership law of requiring undefined obligation of good faith and fair dealing).

"The ULA lists no Notes of Decisions under Section 404 of the RUPA, and a Lexis search produced only six case references to the RUPA, none of which mentions Section 404 or pertains to the duty of care. 
makes two conclusions. First, this Part concludes that the RUPA duty of care provision is intended to apply to all conduct by partners, including managerial decisions, thus supplanting both the partner's duty of care and skill as a paid agent and the business judgment rule. Second, this Part concludes that the section is exclusive, such that partners' managerial decisions are not subject to judicial caveats to the business judgment rule such as the requirement of a "reasonable decision-making process." Instead, a partner's failure to gather or to consider relevant information is subject to the same gross negligence standard as any other conduct. The result is a unitary duty of care based entirely upon conduct that is grossly negligent or worse.

\section{COMMON LAW AND UPA DUTIES OF CARE AMONG PARTNERS}

\section{A. The Basis of Partnership Law in Agency Law}

Historically, the law of partnership has been dominated by the common law of agency, to the extent that the two are "interwoven. ${ }^{12}$ Indeed, the UPA explicitly incorporates principles of agency, ${ }^{13}$ and the Restatement (Second) of Agency quotes the UPA in distinguishing agents and partners. ${ }^{14}$ The Comment to Section 14A of the Second Restatement expands on the relationship between partnership and agency law:

The rules concerning the creation of a partnership and the rights of individual partners and of creditors upon the dissolution of the partnership are matters not dependent upon agency principles. However, the rights and liabilities of partners with respect to each other and to third persons are largely determined by agency principles. ${ }^{15}$

The final sentence is hedged to allow for judicial innovations unknown to classic agency law, such as the business judgment rule.

While most courts and scholars agree that partners owe each other some duty of care under the UPA, there are some who argue that partners owe each other no duty of care whatsoever. Ad-

\footnotetext{
${ }^{12}$ Donald J. Weidner and John W. Larson, The Revised Uniform Partnership Act: The Reporters' Overview, 49 Bus Law 1, 21 (1993).

${ }^{13}$ UPA \& 4(3), 6 ULA 250 (stating that "[t]he law of agency shall apply under this Act"). See also id § 9, 6 ULA 400 ("Partner Agent of Partnership as to Partnership Business"); id § 20, 6 ULA 602 ("Duty of Partners to Render Information"); id § 21, 6 ULA 608 ("Partner Accountable as a Fiduciary"), each of which explicitly codifies agency-based duties.

14 Restatement (Second) of Agency § 14A. Compare with UPA § 6(1), 6 ULA 256.

${ }^{15}$ Restatement (Second) of Agency $\S 14$ A Comment a.
} 
ditionally, others disagree strongly about what that duty is. ${ }^{16}$ Specifically, scholars disagree as to whether the business judgment rule exempts managerial decisions from the standard of care applicable to partners' other actions as agents of the partnership. ${ }^{17}$ Whereas Section $9(1)$ explicitly states that a partner is an agent of the partnership in the context of dealings with third parties, Sections 18-23, dealing with "Relations of Partners to One Another," make no such statement. Indeed, even Section 21, titled "Partner Accountable as a Fiduciary," is "basically merely an anti-theft provision." 18 Thus, while courts have based their jurisprudence regarding issues among partners upon the traditional agent's duties of loyalty and care, ${ }^{19}$ they have adapted agency law to the issues specific to partnerships through doctrines such as the business judgment rule.

The case law demonstrates that the duty of care for a partner under the UPA is actually a bifurcated duty, with a different standard for managerial decisions than for other conduct as the partnership's agent. The latter is a more stringent standard based upon the duty of care owed by paid agents under Section 379 of the Restatement, while the former is a deferential standard akin to the business judgment rule. ${ }^{20}$

${ }^{16}$ Compare Claire Moore Dickerson, Is It Appropriate to Appropriate Corporate Concepts: Fiduciary Duties and the Revised Uniform Partnership Act, 64 U Colo L Rev 111, 114-22, 151-56 (1993) (arguing that agency law has imposed ordinary care standard on partners, and advocating continuation of ordinary care standard under RUPA); Norwood P. Beveridge, Jr., Duty of Care: The Partnership Cases, 15 Okla City U L Rev 753, 755-66 (1990) (arguing that ordinarily prudent person standard, with business judgment rule, should apply under RUPA), with Alan R. Bromberg and Larry E. Ribstein, 2 Bromberg and Ribstein on Partnership $\S 6.07(a)$ at 6:110 (Aspen 1997) (arguing that duty of care applicable to paid agents is inappropriate for partners); Michael L. Keeley, Note, Whose Partnership Is It Anyway?: Revising the Revised Uniform Partnership Act's Duty-of-Care Term, 63 Fordham L Rev 609, 617-21 (1994) (arguing that courts should have discretion to determine on a case-by-case basis whether to apply an ordinary care standard); Larry E. Ribstein, A Mid-Term Assessment of the Project to Revise the Uniform Partnership Act, 46 Bus Law 111, 140-41 (1990) (arguing that partners do not, and should not, owe each other a duty of care).

${ }^{17}$ Compare Beveridge, 15 Okla City U L Rev at 755-66 (cited in note 16), with Dickerson, 64 U Colo L Rev at 117-22, 151-56 (cited in note 16).

${ }^{18}$ ABA Report, 43 Bus Law at 151 (cited in note 4).

19 See, for example, Latta $v$ Kilbourn, 150 US 524, 543 (1893) (holding that real estate purchases by partners were transactions independent of partnership); Salhinger $v$ Salhinger, 56 Wash 134, 105 P 236, 237 (1909) (holding that partner is obligated to disclose relevant information about partnership when terminating relationship).

${ }^{20}$ Because this viewpoint is ably described by Beveridge, 15 Okla City U L Rev at 75660 (cited in note 16), this Comment will only summarize it briefly. See Parts I.B-I.C. This Comment, however, disagrees with Beveridge's conclusions regarding the applicability of the UPA case law to the RUPA rule as enacted. Compare Beveridge, 15 Okla City U L Rev at 761-66, with Parts II.B-II.C. Professor Beveridge was a member of the ABA Subcommittee on the RUPA. 


\section{B. Duty to Use Care and Skill: Ordinary Care Standard}

In cases involving the duty of care among partners, courts have paid close attention to the duty of care and skill owed by paid agents. According to the Restatement (Second) of Agency, a paid agent must "act with standard care and with the skill which is standard in the locality for the kind of work which he is employed to perform" and must "exercise any special skill that he has." ${ }^{21}$ Comment a to the Restatement states that "[a]n agreement with the principal that the agent is not to be liable to him for negligence not of a gross character is legal. ${ }^{.22}$ Thus, under the law of agency, actions taken by a paid agent are subject to a waivable rule of "standard care."

The partnership case law reflects a duty of care that, while worded in various forms, is ultimately comparable to the agency "standard care" rule. Classic case law held partners liable solely for their "culpable negligence," which Beveridge equates with ordinary negligence. ${ }^{24}$ Partners were not, however, liable for errors in judgment if they exercised due care and acted consistently with the judgment of a reasonable person. ${ }^{25}$ The most common modern formulations are a standard of "ordinary care" or of an "ordinarily prudent person," as illustrated in Rosenthal $v$ Rosenthal. ${ }^{26}$ There, the plaintiff sued his brother and partner for breach of fiduciary duty related to the sale of the plaintiff's interest in the family business. The court held that partners, when dealing with one another, shall "act with that degree of diligence, care and skill which ordinarily prudent persons would exercise under similar circumstances in like positions. ${ }^{.27}$

A corollary of the duty to use ordinary care and skill is that, when a partner violates that duty, the other partners cannot be forced by the "culpable" partner to share in the related losses. For example, in Kiffer $v$ Bienstock, ${ }^{28}$ the court held that a partner who negligently injured a third party in an automobile accident while on partnership business, and then was held liable in his personal capacity, was not entitled to contribution by his copartner on dis-

21 Restatement (Second) of Agency § 379(1).

22 Id § 379 Comment a.

See Beveridge, 15 Okla City U L Rev at 756 (cited in note 16), citing Ernest H. Scamell and R.C. l'Anson Banks, Lindley on the Law of Partnership 562 (Sweet \& Maxwell 15th ed 1984).

${ }^{24}$ Beveridge, 15 Okla City U L Rev at 756 (cited in note 16).

${ }^{25}$ See id at 756-57.

${ }^{28} 543$ A2d 348, 352 (Me 1988).

${ }^{27}$ Id.

${ }^{23} 128$ Misc 451, 218 NYS 526 (NY Mun Ct 1926). 
solution of the partnership. ${ }^{29}$ The court applied the agency principle of respondeat superior in holding that, while the negligent partner was primarily liable, the partnership was only secondarily and vicariously liable for the actions of its agent. Therefore his copartner had no responsibility to share in the loss as against him. ${ }^{30}$ Courts have reached the same result in other cases, ${ }^{31}$ reflecting a general pattern under the UPA of forcing partners to bear the costs of their own violations of their duty, as agents, to use care and skill.

Surprisingly, an important hornbook, Bromberg and Ribstein on Partnership, disagrees with the holdings of these cases and states that partners "are not subject to the ordinary care standard applicable to a paid agent. ${ }^{332}$ As discussed at length by Professor Beveridge, these scholars reach this erroneous conclusion by relying on cases in which the court either found no negligence as a matter of fact or applied the business judgment rule. ${ }^{33}$ While the first line of reasoning merits little discussion, the latter represents an important aspect of the partner's duty of care that often supersedes the duty to use care and skill as an agent of the partnership.

\section{Managerial Decisions: Business Judgment Rule}

The business judgment rule is not a new concept to the law of partnership. According to one partnership law scholar, "a partner is not liable to his copartners for a loss caused by an honest mistake of judgment, unless it amounts to gross negligence or ignorance. ${ }^{34}$ In contrast, the common law holds other paid agents who commit errors of judgment liable to their principal unless they act with standard knowledge and care. ${ }^{35}$ The Rosenthal court recognized the business judgment rule in a more modern form. After stating the standard of ordinary care for partners acting as agents, the court stated that "it falls outside of the proper judicial

218 NYS at 528.

${ }^{30} \mathrm{Id}$.

${ }^{31}$ See, for example, Flynn $v$ Reaves, $135 \mathrm{Ga}$ App 651, 218 SE2d 661, 662-63 (1975) (applying ordinary care standard in medical malpractice suit and disallowing negligent partner's suit against partnership for indemnification); United Brokers' Co v Dose, 143 Or 283, 22 P2d 204, 205 (1933) (applying ordinary care standard where partner's negligence caused car accident and disallowing negligent partner's suit for contribution). See generally Beveridge, 15 Okla City U L Rev at 756-60 (cited in note 16).

${ }^{32}$ Bromberg and Ribstein, 2 Partnership $\$ 6.07(f)$ at 6:141 (cited in note 16).

${ }_{33}$ Beveridge, 15 Okla City U L Rev at 755, 761-65 (cited in note 16).

3 T. Parsons, A Treatise on the Law of Partnership 194-95 (Little, Brown 4th ed 1893) (revised by Joseph Henry Beale, Jr.) (footnote omitted).

${ }^{35}$ Restatement (Second) of Agency $\$ 379$ Comment c. 
domain to inquire into and second-guess the prudence of particular business decisions honestly reached by those entrusted with the authority to determine what course of action best advances the well-being of the enterprise. ${ }^{136}$ The court explained that "[q]uestions of policy of management, expediency of contracts or action, adequacy of consideration, lawful appropriation of corporate funds to advance corporate interests, are left solely to [the directors'] honest and unselfish decision ... although the results show that what they did was unwise or inexpedient. ${ }^{\$ 37}$

The court then vacated the special finding of the jury belowthat the defendants had violated their fiduciary duties to the plaintiff ${ }^{38}$-on the basis that "the presiding justice told the jury that the business judgment rule would come into play only if defendants had not otherwise violated the duty of care," permitting the inference that the ordinarily prudent person standard applied to the defendants' managerial decisions. According to the court, "That is not the law." ${ }^{39}$ The court continued, "the business judgment rule will insulate from a finding of liability the informed business judgment decisions made by [defendants] unless their .. . conduct was primarily motivated by fraud or bad faith. ${ }^{240}$ It concluded that " $[t] 0$ assess the ordinary prudence of defendants' business decisions ... [is] a function denied to judicial tribunals. $" 41$

The Rosenthal court's enumeration of business judgment situations underscores two points. First, the difference between situations in which partners exercise care and skill as agents, and those in which they exercise managerial judgment, must be distinguished before a court can apply the appropriate standard. ${ }^{42}$

${ }^{3}$ Rosenthal, 543 A2d at 353.

${ }^{3}$ Id, quoting Auerbach $v$ Bennett, 47 NY2d 619, 393 NE2d 994, 1000 (1979), quoting Pollitz $v$ Wabash Railroad Co, 207 NY 113, 100 NE 721, 724 (1912).

${ }^{33}$ Rosenthal, 543 A2d at 353.

3 Id.

${ }^{4}$ Id.

1 Id at 354.

${ }^{42}$ See, for example, Bane $v$ Ferguson, 890 F2d 11, 14 (7th Cir 1989) (stating in dicta that the business judgment rule would apply where managerial decisions of current partners negligently permitted loss of retirement benefits for a former partner). While operating an automobile or funding a new project are examples at the extremes, many cases fall into a gray area in between, in which judges have significant discretion to choose the standard that they think will achieve a just result. Even in corporate law, where the business judgment rule is well established, it can be difficult to identify when to apply the business judgment rule. For example, in Brane $v$ Roth, 590 NE2d 587 (Ind App 1992) a corporate law case, plaintiffs (shareholders) alleged that failure to hedge against changing prices had caused a loss to the grain cooperative for which defendants were directors. Id at 589. The court held that the directors could be held liable despite the business judgment rule because they failed to inform themselves adequately about the issue of hedging and 
In Part II.C this Comment will discuss whether such distinctions should be made under the RUPA.

Second, scholars who for policy reasons prefer a stronger or weaker duty of care have repeatedly mischaracterized the UPA standard. For example, some scholars deny that the ordinary care standard for agents applies to partners at all. ${ }^{43}$ These scholars advocate a more lenient standard of care for partners. ${ }^{44}$ Conversely, scholars such as Professor Dickerson, who advocate a heightened standard of care among partners, ${ }^{45}$ focus on the duties of partners as agents. Professor Dickerson questions whether the business judgment rule applies at all to general partnerships under the UPA. ${ }^{46}$ Whereas the former group argues against any application of the ordinary care standard under the UPA, the latter group seeks to apply the ordinary care standard even where the business judgment rule or a contractual waiver should control. ${ }^{47}$ Part I.B discussed the former position. This Part now discusses the latter.

Despite the clear evidence of cases like Rosenthal, proponents of the latter view rely largely on Roper $v$ Thomas ${ }^{48}$ to support the proposition that the business judgment rule does not apply to protect general partners when they make negligent managerial decisions. ${ }^{49}$ This reliance is misplaced. The Roper court rejected the defendants' argument that "a general partner may be

failed to supervise adequately the manager concerning the hedging. Id at 591-92. The court could alternatively have found the directors' actions to have fallen within the business judgment rule, because they were relying on the financial expertise of their general manager. Id at 589 .

${ }^{43}$ See Bromberg and Ribstein, 2 Partnership $\$ 6.07$ (f) at 6:141 (cited in note 16).

" Id $\$ 6.07(\mathrm{a})$ at 6:110. Case law demonstrates that this position is erroneous. See Part I.B.

45 Dickerson, 64 U Colo L Rev at 151-56 (cited in note 16).

${ }^{48} \mathrm{Id}$ at $147 \mathrm{n} 187$.

${ }^{47}$ It is vital to remember that the UPA and RUPA both represent default rules. As one scholar has noted:

[P]artnership may exist with or without a partnership agreement, and both the UPA and RUPA exist to "fill gaps" that may exist in any such arrangement either because there is no formal partnership agreement or because the agreement does not address particular situations under the law. Thus, the actual bargained partnership agreement controls, and the provisions in UPA/RUPA come into play only when the agreement either does not exist or is silent on an issue.

Phillips, Comment, $64 \mathrm{U}$ Colo L Rev at $1181 \mathrm{n} 15$ (cited in note 10). The extent to which the UPA and RUPA duty of care rules are, or should be, waivable is, however, a matter of much controversy. See note 58.

${ }^{48} 60$ NC App 64, 298 SE2d 424 (1982).

${ }^{49}$ See, for example, Anthony v Padmar, Inc, 230 SC 436, 465 SE2d 745, 752 n 7 (SC App 1995) (citing Roper to support assertion that partners have higher fiduciary duty to one another); Hooper $v$ Musolino, 234 Va 558, 364 SE2d 207, 211-12 (1988) (holding Roper applies to limited, not general, partnerships). 
likened to a corporate director" who may not be held liable "for error of judgment made in good faith. ${ }^{550}$ The court, however, explained that this argument was "meritless" as a matter of fact, not of law: "Defendants breached their obligations under the partnership agreement . . . . They were negligent in performance of the contract with the plaintiff."31 Because the duty of care under the UPA is a default rule that can be varied by the parties via the partnership agreement, an explicit contractual provision may supersede the business judgment rule. Such a waiver occurred in Roper. ${ }^{52}$

In summary, the UPA established a bifurcated duty of care for partners. A partner's actions as an agent of the partnership were subject to an "ordinary care" standard while actions as a manager of the partnership were subject to the more lenient business judgment rule.

\section{THE RUPA'S DUTY OF CARE PROVISION}

The RUPA, unlike the UPA, provides an explicit duty of care for partners. Partners' common law fiduciary duties under the UPA are replaced under the RUPA by Section 404, titled "General Standards of Partner's Conduct. ${ }^{.53}$ Section 404(a) provides

\footnotetext{
${ }^{30} 298$ SE2d at 429.

s1 Id (emphasis added).

${ }^{82}$ See Ribstein, 46 Bus Law at 140-41 \& 110 (cited in note 16).

83 The official Comment to Section 404 describes the intended role of the section:
}

1. Section 404 is new .... Section 404 is both comprehensive and exclusive. In that regard, it is structurally different from the UPA which touches only sparingly on a partner's duty of loyalty and leaves any further development of the fiduciary duties of partners to the common law of agency. Compare UPA Sections 4(3) and 21.

Section 404 begins by stating that the only fiduciary duties a partner owes to the partnership and the other partners are the duties of loyalty and care set forth in subsections (b) and (c) of the Act. Those duties may not be waived or eliminated in the partnership agreement, but the agreement may identify activities and determine standards for measuring performance of the duties, if not manifestly unreasonable. See Sections 103(b)(3)-(5).

Section 404 continues the term "fiduciary" from UPA Section 21, which is entitled "Partner Accountable as a Fiduciary." Arguably, the term "fiduciary" is inappropriate when used to describe the duties of a partner because a partner may legitimately pursue self-interest (see Section 404(e)) and not solely the interest of the partnership and the other partners, as must a true trustee. Nevertheless, partners have long been characterized as fiduciaries. See, e.g., Meinhard v. Salmon, 249 N.Y. 458, 463, 164 N.E. 545, 546 (1928) (Cardozo, J.). Indeed, the law of partnership reflects the broader law of principal and agent, under which every agent is a fiduciary. See Restatement (Second) of Agency $\S 13$ (1957).

3. Subsection (c) is new and establishes the duty of care that partners owe to the 
that "[t]he only fiduciary duties a partner owes to the partnership and the other partners are the duty of loyalty and the duty of care set forth in subsections (b) and (c). ${ }^{954}$ Section 404(c) describes the "duty of care" for partners under the RUPA as "limited to refraining from engaging in grossly negligent or reckless conduct, intentional misconduct, or a knowing violation of the law. ${ }^{255} \mathrm{Al}-$ though a default provision, ${ }^{56}$ the RUPA duty of care has a mandatory aspect, ${ }^{57}$ which likely prohibits prospective, contractual waiver of the duty of care except on a limited basis with informed consent by the waiving parties. ${ }^{58}$

The text of Section 404(c) applies a gross negligence standard without distinguishing between a partner's duty to use care and skill as an agent and a partner's duty of care as a decisionmaker under the business judgment rule. Three conclusions are possible: (1) the RUPA is not intended to apply to a partner's use of care and skill as an agent of the partnership; (2) it is not intended to apply to a partner's managerial decisions, deferring to the business judgment rule; or (3) it does not differentiate between the two, leaving the same standard for both. This Part argues that, taking into account both the drafters' intentions and policy con-

partnership and to the other partners. There is no statutory duty of care under the UPA, although a common law duty of care is recognized by some courts. See, e.g., Rosenthal v. Rosenthal, 543 A.2d 348, 352 (Me. 1988) (duty of care limited to acting in a manner that does not constitute gross negligence or wilful [sic] misconduct).

The standard of care imposed by RUPA is that of gross negligence, which is the standard generally recognized by the courts. See, e.g., Rosenthal v. Rosenthal, supra.

RUPA § 404 Comment, 6 ULA 59-60. UPA § 21, entitled "Partner Accountable as a Fiduciary," pertains to partners' liability to account to, and hold as trustee for, the partnership for any benefit or unconsented profits derived in connection with the partnership or use of its property. See UPA § 21, 6 ULA 608.

6 ULA 58.

${ }^{B 5}$ Id.

${ }^{B A}$ RUPA § 103(a) provides: "To the extent the partnership agreement does not otherwise provide, this [Act] governs relations among the partners and between the partners and the partnership." 6 ULA 16. Note that the wording of this provision straddles the entity and aggregate theories of partnership: under an entity theory, partners owe their duties to the partnership itself; under an aggregate theory, as under the common law of agency, the partners act as agents of each other, and owe duties to each other as individuals. See text accompanying notes 23-27. Movement away from the aggregate theory under the RUPA is conceptually consistent with movement away from a law of partnerships based upon the common law of agency, as embodied in cases like Kiffer and Flynn $v$ Reaves. See notes 28-31 and accompanying text.

${ }^{57}$ See RUPA $\S 103(\mathrm{~b})(4), 6$ ULA 16, which provides that although the duty of care can be modified by agreement among the partners, it cannot be "unreasonably reduced." See also RUPA \& 103 Comment 6, 6 ULA 18.

The waivability of a partner's duties under RUPA $\S 103$ has been explicitly left for the courts to resolve, RUPA $\$ 103$ Comment 6 , but does not affect this Comment's conclusions, which primarily analyze the RUPA's default provisions when unmodified by contract. 
siderations, the third formulation provides the best interpretation of RUPA $\$ 404$.

\section{A. The RUPA's Duty of Care: Background, Process, and Resolution}

Sources detailing the reasoning of the ABA subcommittee in adopting the RUPA are helpful in determining the intentions underlying the duty of care provision. Such sources include the $A B A$ Report, ${ }^{59}$ articles by the official Reporter, ${ }^{60}$ the RUPA's Prefatory Note, ${ }^{61}$ and the official Comment to Section $404 .{ }^{62}$ All of the sources indicate that the RUPA's drafters intended to apply only the gross negligence duty of care standard among partners.

\section{The $A B A$ Report.}

In its report recommending revision of the UPA, the UPA Revision Subcommittee ${ }^{63}$ stated that " $[w]$ ith respect to inter se rights and obligations between partners and the partnership, the UPA should contain rules that provide a reasonable and equitable framework for resolving the basic problems that are encountered in a hypothetical 'typical' partnership." Specifically, the Subcommittee recommended that "[t]he fiduciary duties of partners to each other and the partnership should be made more explicit, similar to the formulation in the 1984 Model Business Corporation Act [("MBCA")]."65 With regard to UPA \& 21, the provision outlining the fiduciary duties of partners, the Subcommittee recommended that it "be revised to incorporate the full range of

so 43 Bus Law 121 (cited in note 4).

${ }^{60}$ See generally Donald J. Weidner, Three Policy Decisions Animate Revision of Uniform Partnership Act, 46 Bus Law 427 (1991) (reviewing revised UPA before final draft approved); Weidner and Larson, 49 Bus Law 1 (cited in note 12) (discussing implications of final revisions); Donald J. Weidner, The Revised Uniform Partnership Act Midstream: Major Policy Decisions, 21 U Toledo L Rev 825 (1990) (evaluating efforts to revise the UPA). In the Three Policy Decisions article, Weidner refers to the RUPA drafters being motivated by three policy decisions. They are: the emphasis of default rules rather than mandatory rules; the movement away from the aggregate theory and toward the entity theory; and a "major overhaul" of the rules regarding partnership breakups. 46 Bus Law at 470 .

${ }^{61} 6$ ULA 2-5.

2 Id at 59-62.

* This was a subcommittee of the Committee on Partnerships and Unincorporated Business Organizations of the ABA's Section on Business Law.

${ }^{64} A B A$ Report, 43 Bus Law at 123 (cited in note 4).

${ }^{65}$ Id at 126. MBCA $\S 8.30$, entitled "General Standards for Directors," provides that "(a) A director shall discharge his duties ... (1) in good faith; (2) with the care an ordinarily prudent person in a like position would exercise under similar circumstances; and (3) in a manner he reasonably believes to be in the best interests of the corporation." MBCA $\S 8.30$ (Prentice Hall 1994). 
fiduciary duties developed by the cases (due care, good faith, loyalty, and full disclosure of all material facts). ${ }^{366}$ The Subcommittee also suggested that the business judgment rule be applied to "action by partners on behalf of the partnership."

In promulgating the RUPA, the Subcommittee's avowed purpose was to meet the needs of the "hypothetical 'typical' partnership. ${ }^{368}$ While the $A B A$ Report's introduction lists a number of statistics regarding partnerships of different sizes, ${ }^{69}$ the RUPA's "primary focus ... is the small, often informal, partnership. Larger partnerships generally have a partnership agreement addressing, and often modifying, many of the provisions of the partnership act. ${ }^{m 0}$ Thus, the RUPA is intended to address the concerns of the smaller partnership, which is often not represented by counsel, for the simple reason that such partnerships are most likely to rely on the default rules provided by the Act. This policy consideration is very significant. ${ }^{71}$

A conclusion that can be drawn from the Subcommittee's avowed purpose "to incorporate the full range of fiduciary duties developed by the cases" is that they intended an explicit, comprehensive treatment of partners' duties. The most plausible understanding of the Subcommittee's language is that the RUPA duty of care provision is intended to be complete on its face.

\section{Intent of the RUPA's official Reporter.}

The official Reporter for the RUPA project was Donald J. Weidner, a professor at Florida State University College of Law. ${ }^{72}$ Professor Weidner wrote three articles over the course of the drafting process, chronicling and commenting thereon. ${ }^{73}$ Professor

${ }^{66} A B A$ Report, 43 Bus Law at 151 (cited in note 4) (citation omitted).

"Id.

${ }^{68}$ Id at 123 .

${ }^{69}$ Id at 121-22 (using 1981 figures).

${ }^{70}$ RUPA Prefatory Note, 6 ULA 3.

"See Part II.B.2.

72 The responsibility of the official Reporter is to serve as a member of the Drafting Committee to Revise the Uniform Partnership Act and to provide a record of the progressing discussions. The reporter is not merely a scribe, but rather an expert in his own right. According to Professor Weidner:

The task of Reporter is difficult for various reasons. . . The role is an awkward one. The Reporter is expected to have and express his own opinions. At the same time, the Reporter should refrain from any attempt to force his opinions on the Drafting Committee. It is the job of the Reporter to serve the Drafting Committee, not the reverse. ... Happily, I find myself an enthusiastic supporter of most of the major policy decisions of the Drafting Committee.

Weidner, 21 U Toledo L Rev at 858 (cited in note 60).

${ }^{73}$ See note 60. Professor Weidner begins each article with the disclaimer that the 
Weidner's description of the ongoing debate illuminates the viewpoints of the Drafting Committee. In his article Major Policy Decisions, Weidner noted that members of the Subcommittee were

disappointed with the continued use of the word "fiduciary." ... The very word is troublesome, the sentiment seemed to be, because it is subject to abuse in the hands of judges, academics and others whose flow of satisfactions is derived in far too large a part from imposing their personal values on the more productive members of society. ${ }^{74}$

The duties among partners have certainly been subject to the whims of judges, who, some might argue, at times sacrifice the intentions of partners to their own moral sensitivities, via the imposition of open-ended fiduciary principles. ${ }^{75}$ If the Drafting Committee sought to bring about greater predictability regarding the resolution of disputes among partners, an appropriate tool would be language intended to limit the discretion of judges. This language would be consistent with the Subcommittee's avowed purpose to draft an explicit, comprehensive act.

The Drafting Committee, consistent with the recommendations of the $A B A$ Report, at first based the draft RUPA's duty of care provision on MBCA $\S 8.30(\mathrm{a}) .^{76}$ The Committee, however, was ultimately "not yet prepared to impose a 'prudent person' liability rule among partners." The Committee also rejected "reasonable care" and "standard care and skill" liability rules, reasoning that "the default rule should require partners to share the losses caused by each other's ordinary negligence. ${ }^{m 8}$

The Committee appears to have rejected the agency-based case law standard, in favor of a more lenient standard comparable to gross negligence. Professor Weidner states that "[ $t]$ he Drafting Committee has attempted to craft default rules that are efficient and fair. The basic idea is that default rules should re-

views expressed therein are his own.

7" Weidner, 21 U Toledo L Rev at 849 (cited in note 60).

${ }^{75}$ See, for example, then-Chief Judge Cardozo's opinion in Meinhard $v$ Salmon, 249

NY 458, $164 \mathrm{NE} 545,546$ (1928) (evaluating responsibilities among joint venturers).

${ }^{76}$ See note 65 for the text of MBCA $\$ 8.30$.

$"$ Weidner, $21 \mathrm{U}$ Toledo L Rev at 851 (cited in note 60).

${ }^{78}$ Id. Professor Weidner notes the continuing debate over the issue:

The Drafting Committee has not yet decided whether to state a duty of care among partners beyond any that might be implicit in the duty of good faith and fair dealing. Most basically, the Committee is unsure about stating that partners owe each other the duty to use reasonable care. First, there are conflicting statements on the duty of care partners owe each other. Second, it is not clear what the law ought to be.

Weidner, 46 Bus Law at 465 (cited in note 60 ). 
flect what most partners would regard as implicit in their partnership agreements. ${ }^{779}$ The Committee's choice of standard is entirely consistent with the presumed needs and desires of the "typical partnership" for which the RUPA is drafted, and the rules that such partnerships would find to be "efficient," "fair," and "implicit in their partnership agreements." more lenient standard was ultimately calculated to be the best way to meet these criteria.

\section{The RUPA's official Comments.}

The most striking aspect of the official Comment to Section 404(c) is its aggressive treatment of Rosenthal: "The standard of care imposed by RUPA is that of gross negligence, which is the standard generally recognized by the courts." ${ }^{782}$ Recall that Rosenthal clearly illustrates the bifurcated duty of care standard for partners under the UPA. The Subcommittee's treatment of Rosenthal is open to two possible interpretations. The Subcommittee might be focusing on the managerial decisionmaking/business judgment rule aspect of the common law duty of care, without recognizing the ordinary care standard for the partner's duty to use care and skill as an agent. Alternatively, the Subcommittee might be mischaracterizing the ordinarily prudent person standard, which is clearly stated in Rosenthal, as gross negligence. Regardless of which is correct, the Committee's intention regarding the gross negligence standard is clear: it should be applied without regard to standards embodied in existing case law. The Drafting Committee correctly states that there is no statutory duty of care under the UPA, and that any duty thus far recognized by the courts is based on common law. Section 404(a) is explicit that all such common law standards are preempted by the RUPA.

\section{B. Duty to Use Care and Skill: Policy Considerations}

The Subcommittee's approach to RUPA § 404(c) demonstrates two major concerns. The first is the desire for predictability in a legal environment in which open-ended or vague standards will result in judges imposing their own values. ${ }^{83}$ The second is the desire for fair and efficient rules for the so-called "typi-

76 Bus Law at 468 (cited in note 60 ).

${ }^{\infty}$ Id.

${ }^{81}$ For a discussion of Rosenthal, see text accompanying notes 26-27, 36-41.

${ }^{22}$ RUPA $\$ 404$ Comment 3, 6 ULA 60, citing Rosenthal, 543 A2d 348.

See text accompanying notes 74-75. See also note 42 . 
cal partnership, ${ }^{n 44}$ and the determination that such partnerships would desire a more lenient standard than that of the common law of agency. This Part evaluates these policy considerations and responds to counterarguments presented from a variety of sources. It concludes that these policy considerations indicate that the RUPA drafters intended to apply a unitary standard of gross negligence to all actions by partners, whether as an agent or as a manager.

\section{Predictability of adjudication.}

Because fiduciary duties originate from the law of trusts, they are equitable in nature, and provide judges with considerable discretion in their administration. ${ }^{85}$ Such discretion, particularly when coupled with the common law's bifurcated standard of care among partners, creates an environment in which the outcome of litigation under the UPA's default rules is often unpredictable. ${ }^{86}$ Scholars have connected uncertainty regarding anticipated outcomes of litigation with the refusal of parties to settle. $^{87}$

The RUPA's drafters sought to increase the predictability of litigation through several means. First, the RUPA's duty of care is intended to replace that of the common law of agency in the context of disputes among partners. ${ }^{88}$ Second, the RUPA enacts a unified gross negligence standard of care for all partner actions, as opposed to the bifurcated standard under both the common law and the UPA. ${ }^{89}$ Finally, the drafters appear intent on avoiding litigation among partners altogether by implementing a leni-

\footnotetext{
See text accompanying notes 68-70.

ss See Tamar Frankel, Fiduciary Law, 71 Cal L Rev 795, 815-24 (1983) (discussing court administration of fiduciary duties generally).

${ }^{86}$ See text accompanying and following note 75.

${ }^{87}$ See, for example, Richard A. Posner, Economic Analysis of Law 555-56 (Little, Brown 4th ed 1992) (describing a simple model in which "[i]f the parties agree on the probability that the plaintiff will win ... the case will be settled .... In general, then, litigation will occur only if both parties are optimistic about the outcome of the litigation"). See generally Robert D. Cooter and Daniel L. Rubinfeld, Economic Analysis of Legal Disputes and Their Resolution, $27 \mathrm{~J}$ Econ Lit 1067 (1989) (using economic tools to predict at what stage legal disputes will be settled given uncertainty); John P. Gould, The Economics of Legal Conflicts, $2 \mathrm{~J}$ Legal Stud 279 (1973) (using miroceconomic theory to analyze how uncertainty affects settlement negotiations); William M. Landes, An Economic Analysis of the Courts, $14 \mathrm{~J} \mathrm{~L} \&$ Econ 61 (1971) (using economic theory and statistics to analyze settlement in criminal cases given uncertainty); Richard A. Posner, An Economic Approach to Legal Procedure and Judicial Administration, $2 \mathrm{~J}$ Legal Stud 399 (1973) (using economic theory to explain how procedural rules affect litigants' decision to settle).

${ }^{88}$ RUPA $\$$ 404(c), 6 ULA 58 \& Comment 3, 6 ULA 60.

$\infty$ Id.
} 
ent default duty of care among them, in favor of loss spreading through partnership accounts.

As discussed in Part II.C, this policy of favoring predictability plays an important role in determining how courts should approach the gross negligence standard with regard to managerial judgments under the RUPA.

2. Desirability of a given default rule for the "typical partnership."

The drafting of a default rule, such as RUPA $\$ 404$ (c), involves policy decisions regarding the constituency at which the rule is targeted:

The problem in designing the appropriate [partnership] statute is that partnership relationships (and, accordingly, the costs and benefits of particular [default] rules) are as variable as the types of businesses that adopt the partnership form. There is little resemblance between a small family farm and a big-city law partnership. ${ }^{90}$

As noted above, the drafters of the RUPA made the choice to address as the typical partnership, "a small, often informal [one]" formed without legal counsel..$^{91}$ Such a partnership is most likely to rely on a statutory default rule regarding issues like the duty of care among partners. ${ }^{92}$ The key is what duty of care provision such partnerships would choose if they could bargain explicitly at no cost. ${ }^{93}$

With regard to partners' use of care and skill, partners can either pool the risk that one of them will act negligently or reserve the right to hold each other liable through the judicial system for individual acts of ordinary negligence. ${ }^{94}$ If we assume that

${ }^{\infty 0}$ Bromberg and Ribstein, 1 Partnership $\$ 1.02(b)$ at 1:26 (cited in note 16).

"1 RUPA Prefatory Note, 6 ULA 3. See text accompanying notes 68-71.

${ }^{2}$ See Randy E. Barnett, The Sound of Silence: Default Rules and Contractual Consent, $78 \mathrm{Va}$ L Rev 821, 822 (1992) ("Many foreseeable contingencies, given their low probability, are better left unnegotiated ex ante in the hopes that they will not materialize or will be handled cooperatively ex post if they do.").

${ }^{23}$ As Professor Ribstein explains:

A partnership statute serves as a "standard form contract" that supplies terms where the parties have not drafted customized terms. These default rules should approximate what the parties would have drafted if they could bargain for and draft all of the rules that govern their relationship without cost. An appropriate set of default rules minimizes the costs and maximizes the benefits of doing business as a partnership, and reduces the parties' need to draft customized terms.

Ribstein, 46 Bus Law at 113-14 (cited in note 16).

${ }^{94}$ See Weidner, 46 Bus Law at 467-68 (cited in note 60); Weidner and Larson, 49 Bus Law at 21-23 (cited in note 12). 
members of small partnerships are more likely than not to be of a level of skill comparable to that of their copartners, the former choice, which is consistent with RUPA $\S 404$ (c), is a preferable default rule. ${ }^{95}$ This assumption is sensible: people who enter small partnerships and risk significant portions of their wealth will probably choose partners that they know and trust to be as careful in their partnership affairs as they would be with their own money. Where this assumption holds, a gross negligence rule has the advantage, first, of smoothing partners' individual income streams over time by pooling risks of partners; and second, of minimizing costs associated with disputes regarding negligent partner actions.

The income-smoothing function of partner risk-pooling is desirable to the extent that partners prefer a more predictable stream of income, a likely situation for risk-averse or risk-neutral partners. Where partners are similarly skilled, each is equally likely to incur liability due to her individual negligence at any given time. Losses due to negligence will occur unpredictably, but over time they will, on average, approach an equal distribution among partners. ${ }^{96}$

Furthermore, not only does the gross negligence rule stabilize partners' portions of the partnership pie over time, it also likely increases the overall size of the pie. This is because partners will not be able to litigate, even upon dissolution, acts of ordinary negligence affecting only each other. Furthermore, they will generally not need to engage in cross-claims or actions for contribution against their copartners when third parties seek to hold the partnership, or a culpable partner, liable for acts of ordinary negligence. ${ }^{97}$ Instead, losses from ordinary negligence are distributed, like any other business expense, through the partnership accounts. ${ }^{98}$

The RUPA also minimizes judicial expense because, under its entity philosophy, RUPA $\S 307$ requires third parties to levy against partnership assets before levying against individual, nonculpable partners. ${ }^{99}$ Thus, where the partnership has sufficient

${ }^{95}$ See Weidner and Larson, 49 Bus Law at $22-23$ (cited in note 12).

${ }^{26}$ See id.

${ }^{97}$ Under RUPA \& 307(d), a claimant must generally levy against partnership assets before pursuing a partner's individual assets (the so-called "exhaustion" rule). RUPA $\S 307(d), 6$ ULA 47. However, once Section 307(d) is satisfied, partners are personally liable jointly and severally for partnership obligations under Section 306(a). RUPA § 306(a), 6 ULA 45.

${ }^{*}$ RUPA § 401(b) provides the default rule that partnership losses are distributed in accordance with partners' shares of partnership profits. RUPA § 401(b), 6 ULA 52.

${ }^{9}$ Note that this change makes Professor Beveridge's counterargument, Beveridge, 15 
assets or insurance to cover a judgment, the typical negligence suit by a third party will require only one judicial action. In addition, because use of the judicial system externalizes some costs of disputes among partners, the benefit of minimizing litigation will accrue to the taxpaying society as well. Finally, even when settlement without litigation would otherwise be possible, partners who can resort to the legal system to settle disputes with their copartners might do so for strategic reasons, such as exploiting a bilateral monopoly.

A key caveat to this argument, however, is that it is uncertain whether removing the threat of inter-partner liability for ordinary negligence will significantly reduce the partners' incentives to take due care. It likely will not for two reasons: first, as part owners and marginal stakeholders of the partnership, partners have good incentives to take care; second, partners share unlimited, joint and several personal liability for partnership losses that exceed partnership assets. ${ }^{100}$ Partners therefore have good reason to take care in their actions and to monitor the care taken by their copartners. They are able to capture among themselves the full benefit of these care and monitoring expenses. ${ }^{101}$

Even where the assumption of comparable skill among partners does not hold-such as where partners have poor information about their respective abilities, or where partners differ in their attitudes toward risk-there is no reason to worry that partners will take less than an optimal level of due care. Partners are still free either to contract reasonably around the default rule, or to take alternative steps, such as purchasing insurance or reallocating assignments, to address their different levels of risk. ${ }^{102}$ Such steps are likely to be more effective and less costly when chosen by the partners, in light of their unique individual situations, than with an allocation of ordinary. risk through a statutory default rule.

3. Counterarguments and alternative policy considerations.

As the official Reporter notes, "At first glance, it might sound preposterous to reject the conclusion that partners owe each other the duty to use reasonable care. ${ }^{\text {"103 }}$ It is clear, however, that the

Okla City U L Rev at 765-66 (cited in note 16), inapplicable, because the liability of individual partners for ordinary negligence, either to their copartners or to third parties, is rendered the same under the RUPA.

${ }^{100}$ RUPA § 306(a), 6 ULA 45.

${ }^{\text {tor }}$ See Weidner, 46 Bus Law at 467-68 (cited in note 60).

${ }^{102}$ See Weidner and Larson, 49 Bus Law at $22-23$ (cited in note 12 ).

${ }^{103}$ Id at 22 . 
RUPA drafters intended precisely this result. This Part addresses the most important of the objections raised by the replacement of the common law ordinary care standard with the RUPA's gross negligence standard.

First, one might argue that the common law standard of care should apply because partners are agents of each other and of the partnership, and therefore owe the fiduciary duties of agents, including the duty to use care and skill. The RUPA, however, is clearly intended both to soften partners' fiduciary duties and to displace the common law duty of care. The Prefatory Note to the RUPA states that "[a]lthough RUPA continues the traditional rule that a partner is a fiduciary, it also makes clear that a partner is not required to be a disinterested trustee. Provision is made for the legitimate pursuit of self-interest, with a counterbalancing irreducible core of fiduciary duties." ${ }^{104}$ Certainly, the pursuit of self-interest is absolutely irreconcilable with the common law's conception of agents owing "the duty of the finest loyalty" and "the punctilio of an honor the most sensitive." 105 Thus, it is clear that the RUPA encompasses a departure from the common law of agency with regard to fiduciary duties generally.

Furthermore, there is strong textual support for the argument that the fiduciary duty of care is to be administered without regard to the common law duty of agents to use care and skill. Section 104(a) of the RUPA states that "[u]nless displaced by particular provisions of this [Act], the principles of law and equity supplement this [Act]. ${ }^{106}$ The Comment to Section 104 indicates that the section incorporates the law of agency. ${ }^{107}$ However, Section 404(a) embodies a clear intent to displace the common law of agency: "The only fiduciary duties a partner owes ... are the duty of loyalty and the duty of care set forth in subsections (b) and (c). ${ }^{\text {108 }}$ Thus, while the RUPA may generally incorporate common law rules of agency, on the specific matter of duties owed between partners, the RUPA rejects the common law standard. There is clearly no ordinary care standard among partners under the RUPA.

A second counterargument, raised by Professor Weidner, is that of fairness among the partners:

\footnotetext{
${ }^{10}$ RUPA Prefatory Note, 6 ULA 4.

${ }^{105}$ Meinhard, 164 NE at 546.

${ }^{106}$ RUPA § 104(a), 6 ULA 20.

${ }^{107} \mathrm{Id}$.

${ }^{100}$ RUPA $\S 404$ (a), 6 ULA 58 (emphasis added).
} 
If a ten percent partner negligently shatters $\$ \mathrm{X}$ of partnership property, why should ninety percent of the loss be borne by the other partners? What if the partner's negligence causes a loss to a third party that not only wipes out all partnership assets but also causes the ninety percent partners to lose their separate assets? Is the goal of distributive justice among partners served if the scrupulously careful ninety percent are wiped out and denied the right to be indemnified by the negligent actor? ${ }^{109}$

This argument, however, suffers from the ex ante/ex post fallacy. If the average small partnership is composed of individuals who are similarly skilled and careful, there is no reason to expect that a large loss due to ordinary negligence is more likely to be incurred by one of them any more than another. Because it is advantageous for partners to pool the risk of such occurrences, and because, in the long term, such losses will fall equally on all partners, the fairness concern disappears. For partners who know that these assumptions do not apply to them, various opportunities to reallocate these risks, by contract or otherwise, are available. ${ }^{110}$

\section{Managerial Decisions and the Business Judgment Rule}

Sources in both partnership and corporation law support the notion that managers must meet some substantive or procedural standards, such as reasonably informing themselves and undertaking a reasonable decisionmaking process, before courts will apply the business judgment rule. ${ }^{111}$

${ }^{109}$ Weidner, 21 U Toledo L Rev at 852 (cited in note 60).

${ }^{110}$ See generally.Part II.C.2.

"Id. Regarding corporate law, see Melvin Aron Eisenberg, The Divergence of Standards of Conduct and Standards of Review in Corporate Law, 62 Fordham L Rev 437 (1993). Professor Eisenberg explains:

The business-judgment rule consists of four conditions, and a special standard of review that is applicable, if the four conditions are satisfied, in suits that are based on the substance or quality of a decision a director or officer has made, as opposed to the decision-making process he utilized to arrive at his decision.

The four conditions are as follows:

First, a judgment must have been made. So, for example, a director's failure to make due inquiry, or any other simple failure to take action-as opposed to a decision not to act-does not qualify for protection of the rule.

Second, the director or officer must have informed himself with respect to the business judgment to the extent he reasonably believes appropriate under the circumstances-that is, he must have employed a reasonable decision-making process.

Third, the decision must have been made in subjective good faith-a condition that is 
While the applicability of such standards to the exercise by partners of their managerial judgment is an open issue, the desire for predictability and the desire to meet the needs of the "typical partnership" provide some insight into this issue and strongly support the argument that all such considerations should be replaced by the gross negligence standard.

\section{Business judgments and predictability.}

Smith $v$ Van Gorkom ${ }^{12}$ is an important example of the judicial caveats that limit the business judgment rule. In Van Gorkom, the Delaware Supreme Court held that the business judgment rule did not protect decisions by corporate directors who were not "reasonably informed. ${ }^{1113}$ The Van Gorkom decision sent shockwaves through the corporate legal community largely because the court's approach to the business judgment rule was so unprecedented. The reaction included a virtual disappearance of directors' and officers' insurance, threats by corporations to leave Delaware, and, ultimately, legislative action to permit corporations to reduce the risk to their directors. ${ }^{14}$ The fear, similar to the concerns about unpredictability expressed in Part II.B.1, was that directors would be unable to predict accurately what actions the judiciary would deem to be insufficiently informed or based on inadequate procedures. The boundaries of the business judgment rule, a doctrine intended to minimize judicial discretion to second-guess managerial decisions, had itself become subject to varying interpretations by judges.

Even in corporate law, the precise standards of these caveats to the business judgment rule are unsettled. This uncertainty is

not satisfied if, among other things, the director or officer knows that the decision violates the law.

Fourth, the director or officer may not have a financial interest in the subject matter of the decision. For example, the business-judgment rule is inapplicable to a director's decision to approve the corporation's purchase of his own property.

If these four conditions are met, then the substance or quality of the director's or officer's decision will be reviewed, not under the basic standard of conduct to determine whether the decision was prudent or reasonable, but only under a much more limited standard.

Id at 441 (citations omitted). See also MBCA $\S 8.30$ (a) \& official Comment. Under this formulation, it is Professor Eisenberg's second condition, that of a reasonable decisionmaking process, that this Comment primarily addresses.

11288 A2d 858 (Del 1985).

"1d Id at 872 .

${ }^{11}$ See An Act to Amend Chapter 1, Title 8 of the Delaware Code, Relating to the General Corporation Law, 69 Del Laws 61 (1993), codified at 8 Del Code Ann $\S 102(b)(7)(1991$ \& Supp 1996) (regarding exculpatory charter provisions). 
reflected in the Comment to MBCA $\S 8.30$, which states that the contours of the business judgment rule are left to the courts to develop. ${ }^{115}$ This situation imposes serious costs. First, risk-averse managers will be less willing to assume managerial roles, and more likely to demand premiums to compensate for the increased risk of incurring liability for a managerial decision. ${ }^{116}$ In the partnership setting, the Van Gorkom default rule will distort the division of responsibilities and compensation among partners. Second, managers will be chilled from pursuing potentially valuable, but risky, projects for fear of liability if these projects fail. Third, managers may be forced to resort to proceduralism and defensive management, holding unnecessary meetings and producing unnecessary documentation in contemplation of possible future litigation. Finally, as discussed above, the increased unpredictability of judicial outcomes makes litigation relatively more likely and settlement less so unless parties are stridently risk averse. ${ }^{117}$

These costs are both significant and incompatible with the intentions of the Drafting Committee. ${ }^{118}$ Below, it is demonstrated that whatever the merits of substantive or procedural caveats to the business judgment rule for other business structures, they are unsuited to general partnerships, especially the "typical partnerships" to which the RUPA default rules are directed.

\section{Business judgments and the "typical partnership."}

The primary goal of procedural and substantive caveats to the business judgment rule is to decrease agency costs by limiting the discretion of manager-agents whose incentives do not match the preferences of their investor-principals. ${ }^{119}$ Thus, by mandating that business decisions be appropriately well considered and informed, these caveats act as proxies for good incentives on the part of management. Therefore, the more closely aligned are the interests of the managers and the investors in an enterprise, the fewer the benefits of these caveats relative to their costs.

In general partnerships, the default rule is that partners have equal rights in the management and conduct of the partner-

${ }^{115}$ MBCA $\S 8.30$ official Comment.

${ }^{116}$ See William A. Sahlman, Why Sane People Shouldn't Serve on Public Boards, 68 Harv Bus Rev 28, 28 (May-June 1990) (discussing risks directors face as corporate board members in wake of Van Gorkom).

${ }^{117}$ See note 87.

${ }^{11}$ See Part II.B.1.

${ }^{119}$ See Frank H. Easterbrook and Daniel R. Fischel, The Economic Structure of Corporate Law 90-100 (Harvard 1991). But see id at 107-08 (criticizing the Delaware Supreme Court's interpretation of the rule in Van Gorkom). 
ship business, ${ }^{120}$ and share equally in partnership profits and losses. ${ }^{121}$ Thus, partners' incentives as managers and owners are nearly identical, and partners capture among themselves the full benefits of good decision making. For the small, relatively simple partnership for which the RUPA is intended, this result holds most true, whereas in a larger and more complex partnership, it is more likely that certain partners will assume designated leadership or managerial roles. In this latter type of partnership, however, it is more likely that partners will have the sophistication to retain counsel and contract around the RUPA default rules.

Finally, from the partners' perspective, it is difficult to make a principled distinction between managerial decisions and other actions on behalf of the partnership. Lack of due care in either situation is inefficient, because it will tend to create liabilities for the partnership -in contract, tort, or otherwise-greater than the expected cost of care. ${ }^{122}$ Partners will thus have incentives, independent of the duty of care default rule, to make careful decisions and to monitor the decision making of their copartners. ${ }^{123}$ To the extent that, from the partners' perspective, lack of due care in managerial decisions is indistinguishable from lack of due care in actions as an agent of the partnership, the arguments of Part II.B-particularly with regard to a partner's incentives to take care, risk pooling, and fairness-apply with full force to the application of the gross negligence standard to managerial decisions. ${ }^{124}$

Ironically, were the courts to apply a gross negligence standard to actions by partners, but a procedurally and substantively qualified business judgment rule to managerial decisions, it would be the latter that would be held, de facto, to a higher level

${ }^{120}$ RUPA § 401(f), 6 ULA 52.

${ }^{121}$ RUPA \& 401(b), 6 ULA 52.

${ }^{12}$ Note that, unlike the UPA, the RUPA holds partners jointly and severally liable, not only for tort obligations, but also for contractual obligations of the partnership. RUPA §306(a), 6 ULA 45.

${ }^{12}$ See Alan R. Bromberg and Larry E. Ribstein, Special Release on the Revised Uniform Partnership Act: Bromberg and Ribstein on Partnership 55-56 (Little, Brown 1993) (questioning the need for duty of care in all partnerships given the incentive to monitor the other partners' behavior).

${ }^{12 x}$ One might question why, if these concepts are "indistinguishable," the judicial system distinguishes between them in the common law of agency and under the UPA. The reason is that they are only identical from the perspective of the partner's choice of whether to take due care. From the perspective of the judicial system, however, evaluation of actions is considered different from evaluation of business decisions. The former are routinely scrutinized under the law of tort; the latter are widely considered to be beyond the realm of judicial competence. This is the basic justification for the business judgment rule. 
of judicial scrutiny and duty of care. Judges would be able to find partners liable for decisions made on the basis of an unreasonable decisionmaking process without regard to the deferential business judgment rule. ${ }^{125}$ The better interpretation is that the Drafting Committee intended the gross negligence standard to apply to the decisionmaking process, in addition to the decision itself.

In summary, the gross negligence standard of care for both managerial decisions by partners and the processes by which those decisions are made is justified because partners' good incentives ensure that "the risk of harm to the partnership [of a partner's ordinary negligence] is frequently outweighed by the need to give the partner sufficient leeway to exercise discretion on behalf of the partnership."126 Under the RUPA, the partner's duty of care is different from that of a common law paid agent, and indeed from that of a corporate director; the standard is that of liability only for gross negligence, or worse, in any of the partner's actions or decisions.

\section{CONCLUSION}

Baron Rolfe once referred to gross negligence as identical to ordinary negligence "with the addition of a vituperative epithet."127 The drafters of the RUPA take the standard more seriously, adopting it as the unitary standard of care among partners for both their actions and their managerial decisions.

This conclusion is compelled by the two primary considerations emphasized by the drafters throughout the RUPA drafting process: (1) predictable judicial administration and (2) the desirability of the "hypothetical typical partnership," a small, uncounseled venture in which, as noted by Professor Weidner, partners are generally of similar levels of skill. ${ }^{128}$ In light of the bifurcated UPA and common law duty of care standard among partners, it is clear that the RUPA's gross negligence standard intentionally breaks from case law imposing an ordinary care standard on partners as paid agents and limiting the business judgment rule

\footnotetext{
${ }^{125}$ While the Van Gorkom court used a gross negligence standard in determining whether the directors should be held liable, the MBCA's reasonableness standard appears to imply a negligence standard.

${ }^{126}$ Bromberg and Ribstein, 2 Partnership $\$ 6.07(f)$ at 6:144 (cited in note 16).

${ }^{127}$ Wilson v Brett, 152 Eng Rep 737, 739 (Ex 1843).

${ }^{12 s}$ Weidner and Larson, 49 Bus Law at $22-23$ (cited in note 12).
} 
through procedural and substantive caveats. This "gross negligence" standard will result both in greater judicial predictability and appropriate incentives for partners to take due care, while minimizing judicial and administrative costs, both to partners and to third parties. 


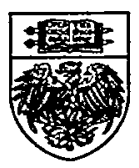

